\title{
PENENTUAN JUMLAH TENAGA KERJA DENGAN METODE KESEIMBANGAN LINI PADA DIVISI PLASTIC PAINTING PT. XYZ
}

\author{
Lina Gozali, Andres dan Feriyatis \\ Program Studi Teknik Industri Universitas Tarumanagara \\ e-mail: linag@ft.untar.ac.id
}

\begin{abstract}
ABSTRAK
PT. XYZ merupakan perusahaan yang bergerak di bidang industri manufaktur bagian otomotif. Adanya bottleneck pada suatu stasiun kerja dikarenakan jumlah operator yang tidak ideal akan menyebabkan efisiensi produksi rendah. Dengan adanya keseimbangan lini dalam suatu sistem produksi akan meningkatkan efisiensi produksi perusahaan. Metode keseimbangan lini yang akan digunakan untuk menyelesaikan permasalahan tersebut yaitu metode Kilbridge-Wester, metode Helgeson-Birnie, metode Moodie Young, dan metode J-Wagon. Efisiensi awal yaitu sebesar 62,27\%, dengan menggunakan metode Kilbridge-Wester, metode Helgeson-Birnie, dan metode J-Wagon didapatkan hasil efisiensi lini yang sama yaitu sebesar 76,24\%, dan efisiensi lini dengan metode Moodie Young yaitu sebesar 80,06\%. Metode Moodie Young merupakan metode terbaik untuk PT. XYZ karena memiliki hasil yang paling baik dalam efisiensi lini, balance delay, smoothness index, waktu siklus, waktu menganggur, dan jumlah stasiun kerja. Waktu siklus yang diperoleh yaitu sebesar 31 detik dengan balance delay sebesar 19,94\%, smoothness index sebesar 29,08 waktu menganggur 86,52 detik, dan 14 stasiun kerja.
\end{abstract}

Kata kunci: Keseimbangan Lini, Waktu Siklus, Efisiensi Lini, Balance Delay, Smoothness Index

\begin{abstract}
PT. XYZ is a company that engaged in automotive manufacturing industry. The bottleneck at some work station because of the number of operators that are not will lead to lower production efficiency. With line balancing in production system will increase the efficiency of production. Line balance method will be used to solve these problemsis Kilbridge-Wester methods, Helgeson-Birnie methods, Moodie Young methods, and J-Wagon methods. Beginning of efficiency is $62,27 \%$, by using Kilbridge-Wester methods, Helgeson-Birnie methods, and J-Wagon methods line efficiency is 76,24\%, and the line efficiency of Moodie Young methods is $80,06 \%$. Moodie Young methods is the best methods for PT. XYZ because it has the best results in efficiency, balance delay, smoothness index, cycle time, idle time, and number of work stations. The cycle time is 31 second with balance delay of 19,94\%, smoothness index of 29,08, idle time of 86,52second, and 14 work stations.
\end{abstract}

Keywords: Line Balancing, Cycle Time, Line Efficiency, Balance Delay, Smoothness Index

\section{PENDAHULUAN}

Suatu perencanaan produksi yang tidak tepat akan dapat mengakibatkan ketidakseimbangan waktu operasi stasiun kerja. Ketidakseimbangan waktu operasi stasiun kerja mengakibatkan ketidakseimbangan lini produksi. Dampak lainya yaitu terjadinya bottleneck dan terdapat waktu dan jumlah pekerja yang menganggur di setiap stasiun kerja. Proses penyeimbangan lini perlu dilakukan untuk menciptakan keseimbangan dari jalur produksi sehingga proses produksi akan berjalan lancar. Penerapan keseimbangan lini dalam suatu sistem produksi akan meningkatkan efisiensi produksi dari perusahaan.

PT. XYZ adalah salah satu industri otomotif yang bergerak di bidang manufaktur.
Perusahaan ini memproduksi dan merakit part kendaraan roda dua. Kurang efektifnya tenaga kerja pada plastic painting line $\mathrm{J}$ mengakibatkan terjadinya bottleneck pada stasiun kerja. Untuk mencapai efisiensi kerja, maka proses bottleneck harus diminimalkan dengan menyeimbangkan jumlah operator pada stasiun kerja dan kecepatan hanger yang ada.

Tujuan dari penelitian ini yaitu untuk mendapatkan jumlah pekerja yang ideal pada plastic painting line J, mencapai balance delay yang minimum, efisiensi lintasan yang optimum, smoothness index terkecil, waktu siklus terpanjang, waktu menganggur yang minimum, dan jumlah stasiun yang optimum. 


\section{TINJAUAN PUSTAKA}

\section{Pengujian Data}

1. Uji Kenormalan

Uji kenormalan data dilakukan untuk mengetahui apakah data yang diperoleh berdistribusi normal atau tidak. Teknik yang digunakan untuk menguji normalitas data, yaitu uji kolmogorov-smirnov. Metode ini merupakan metode uji kenormalan yang paling popular. Uji Kolmogorov-Smirnov terhadap kenormalan data dapat dihitung dengan software SPSS 20.0.

\section{Uji Keseragaman}

Uji keseragaman data dilakukan untuk mengetahui apakah hasil pengukuran waktu cukup seragam. Data dikatakan seragam jika data tersebut berada dalam rentang batas kontrol. Batas kontrol terdiri dari dua batas yaitu Batas Kontrol Atas (BKA) dan Batas Kontrol Bawah (BKB).

\section{Uji Kecukupan}

Uji kecukupan data dilakukan untuk mengetahui apakah data yang diambil sudah cukup atau belum. Data yang akan diuji berasal dari hasil uji keseragaman data. Jika hasil perhitungan $\mathrm{N}^{\prime}<\mathrm{N}$, maka pengamatan yang dilakukan dianggap cukup. Sebaliknya jika N'> $\mathrm{N}$, maka perlu dilakukan pengamatan lagi sebanyak N' dikurang N.

\section{Faktor Penyesuaian}

Perhitungan faktor penyesuaian akan dilakukan dengan menggunakan metode Westinghouse [1]. Perhitungan Westinghouse mengarahkan penilaian pada empat faktor yang dianggap menentukan kewajaran atau ketidakwajaran dalam bekerja yaitu Keterampilan, Usaha, Kondisi kerja dan Konsistensi, Setiap faktor terbagi kedalam kelas-kelas dengan nilai masing-masing. Keterampilan atau skill didefinisikan sebagai kemampuan mengikuti cara kerja yang ditetapkan. Yang dimaksud dengan usaha atau effort yaitu kesungguhan yang ditunjukkan atau diberikan operator ketika melakukan pekerjaannya. Kondisi kerja atau condition adalah kondisi fisik lingkungannya seperti keadaan pencahayaan, temperatur, dan kebisingan ruangan.
Bila tiga faktor lainnya yaitu keterampilan, usaha dan konsisten merupakan apa yang dicerminkan operator, maka kondisi kerja merupkan suatu operator yang diterima apa adanya oleh operator tanpa banyak kemampuan merubahnya. Konsistensi atau Consistency perlu diperhatikan karena kenyataan bahwa pada setiap pengukuran waktu angka-angka yang dicatat tidak pernah semuanya sama; waktu penyelesaian yang ditunjukkan pekerja selalu berubah-ubah dari satu siklus kesiklus lainnya, dari jam ke jam, bahkan dari hari ke hari.

\section{Waktu Normal}

Rating faktor pada dasarnya digunakan untuk menormalkan waktu kerja yang diperoleh dari pengukuran kerja akibat kecepatan kerja operator yang berbeda-beda.

Waktu normal $=$ Waktu siklus $\times(1+$ Penyesuaian).....(1)

\section{Kelonggaran dan Waktu Baku}

Waktu normal semata-mata menunjukkan bahwa seorang operator yang berkualifikasi baik akan bekerja menyelesaikan pekerjaan pada kecepatan kerja yang normal. Pada kenyataannya operator tidak akan mampu bekerja secara terus-menerus tanpa adanya interupsi. Operator akan sering menghentikan kerja dan membutuhkan waktu-waktu khusus untuk keperluan seperti personal needs, istirahat melepas lelah dan alasan-alasan lain di luar kontrolnya. Faktor kelonggaran yang dibutuhkan dan akan menginterupsi proses produksi ini diklasifikasikan menjadi personal allowance, fatigue allowance, dan delay allowance. Sedangkan Waktu baku atau waktu standar adalah waktu normal yang telah memperhitungkan faktor kelonggaran atau allowance tersebut.

Waktu baku $=$ Waktu normal $+(\%$ kelonggaran $\times$ waktu normal)

\section{Keseimbangan Lini}

Menurut Gaspersz, line balancing merupakan penyeimbangan penugasan elemenelemen tugas dari suatu assembly line ke work 
stations untuk meminimumkan banyaknya work station dan meminimumkan total harga idle time pada semua stasiun untuk tingkat output tertentu [2]. Fungsi dari line balancing adalah membuat suatu lintasan yang seimbang. Tujuan pokok dari penyeimbangan lintasan adalah meminimumkan waktu menganggur (idle time) pada lintasan yang ditentukan oleh operasi yang paling lambat. Data yang diperlukan dalam keseimbangan lini adalah informasi tentang waktu yang dibutuhkan untuk setiap assembly line dan precedence relationship.

Berikut ini merupakan langkah-langkah pemecahan masalah adalah sebagai berikut.

a. Mengidentifikasi tugas-tugas individual atau aktivitas yang akan dilakukan.

b. Menentukan waktu yang dibutuhkan untuk melaksanakan setiap tugas itu.

c. Menetapkan precedence constraints, jika ada yang berkaitan dengan setiap tugas itu.

d. Menentukan output dari assembly line yang dibutuhkan.

e. Menentukan waktu total yang tersedia untuk memproduksi output.

f. Menghitung cycle time yang dibutuhkan, misalnya waktu diantara penyelesaian produk yang dibutuhkan untuk menyelesaikan output yang diinginkan dalam batas toleransi dari batas waktu yang diijinkan.

g. Memberikan tugas-tugas kepada pekerja atau mesin.

h. Menetapkan minimum banyaknya stasiun kerja (work station) yang dibutuhkan untuk memproduksi output yang diinginkan.

i. Menilai efisiensi dari solusi.

Terdapat beberapa istilah dalam line balancing yaitu sebagai berikut:

1. Precedence diagram merupakan gambaran secara grafis dari urutan operasi kerja, serta ketergantungan pada operasi kerja lainnya yang tujuannya untuk memudahkan pengontrolan dan perencanaan kegiatan yang terkait di dalamnya.

2. Work element atau elemen kerja merupakan bagian dari seluruh proses perakitan yang dilakukan. Waktu operasi $\left(\mathrm{t}_{\mathrm{i}}\right)$ adalah waktu standar untuk menyelesaikan suatu operasi.
3. Work station (WS) adalah tempat pada lini perakitan di mana proses perakitan dilakukan.

4. Cycle time (CT) atau waktu siklus merupakan waktu yang diperlukan untuk membuat satu unit produk per satu stasiun. Apabila waktu produksi dan target produksi telah ditentukan, maka waktu siklus dapat diketahui dari hasil bagi waktu produksi dan target produksi.

5. Station time (ST) merupakan jumlah waktu dari elemen kerja yang dilakukan pada suatu stasiun kerja yang sama.

6. Idle time (I) merupakan selisih atau perbedaan antara CT dan ST.

7. Balance delay (BD) sering disebut balancing loss adalah ukuran dari ukuran ketidakefisienan lini yang dihasilkan dari waktu menganggur sebenarnya yang disebabkan karena pengalokasian yang kurang sempurna di antara stasiun-stasiun kerja.

8. Efisiensi lini adalah rasio antara waktu yang digunakan dengan waktu yang tersedia.

\section{Metode Keseimbangan Lini}

1. Metode Killbridge Wester (Region Approach)

Metode ini membagi precedence diagram dalam beberapa wilayah secara vertikal, dan pada setiap wilayah tidak boleh ada dua operasi yang berurutan. Pada prinsipnya metode ini berusaha untuk membebankan terlebih dahulu operasi yang memiliki tanggung jawab keterdahuluan yang besar. Berikut merupakan langkah-langkah metode Killbridge Wester adalah sebagai berikut [3]:

a. Bagi precedence diagram yang ada ke dalam beberapa wilayah.

b. Pembagian wilayah ini dilakukan secara vertikal, dimana setiap wilayah tidak boleh ada dua operasi yang saling berhubungan.

c. Operasi yang tidak memiliki operasi pendahulu (predecessor) diletakkan pada wilayah yang pertama/lebih awal.

d. Alokasikan operasi yang terletak pada wilayah yang paling awal kepada stasiun yang lebih awal dengan memperhatikan precedence diagram. 
e. Setiap operasi yang berada pada wilayah yang sama mempunyai hak yang sama untuk dialokasikan kepada stasiun yang ada, oleh karena itu bisa dipih operasi yang mana saja yang akan dialokasikan ke dalam stasiun yang ada.

f. Jika kita akan mengalokasikan operasi yang ada pada wilayah berikutnya, maka seluruh operasi yang ada pada wilayah sebelumnya harus sudah dialokasikan semuanya.

g. Alokasikan seluruh operasi kepada seluruh stasiun yang ada.

h. Perngalokasian operasi kepada salah satu stasiun, total waktu prosesnya tidak boleh melebihi CT (Cycle Time) yang telah ditentukan.

\section{Metode Helgeson-Birnie}

Ranked Position Weight/RPW merupakan suatu metode yang digunakan untuk menyeimbangkan lintasan pada proses produksi dengan diketahui terlebih dahulu waktu-waktu yang ada dalam proses perakitan tersebut dengan tujuan agar proses produksi itu berjalan dengan baik. Berikut merupakan langkahlangkah dari metode Helgeson Birnie adalah sebagai berikut [4]:

a. Lakukan pembobotan dengan cara menentukan jalur/node/jaringan terpanjang dari masing-masing operasi berdasarkan waktu proses dengan melihat kepada precedence yang ada.

b. Jumlahkan waktu operasi dan jalur/node/ jaringan yang telah terbentuk.

c. Urutkan/ranking operasi-operasi berdasarkan waktu terpanjang.

d. Alokasikan operasi yang mempunyai ranking paling awal kepada stasiun yang lebih awal dengan memperhatikan precedence diagram.

e. Alokasikan seluruh operasi kepada seluruh seluruh stasiun yang ada.

f. Pengalokasian operasi kepada salah satu stasiun, total waktu prosesnya tidak boleh melebihi $\mathrm{C}_{\mathrm{T}}$ (Cycle Time) yang telah ditentukan.

\section{Metode Moodie Young}

Pada metode ini terdapat dua tahap analisis yaitu fase satu dan fase dua. Fase satu adalah membuat pengelompokan stasiun kerja berdasarkan matriks hubungan antar elemen kerja, tidak dirangking seperti metode Helgeson Birnie. Sedangkan, fase dua dilakukan revisi pada hasil fase satu. Berikut merupakan penjelasan mengenai fase satu dan fase dua dari metode Moodie Young adalah sebagai berikut:

A. Fase satu, elemen kerja ditempatkan pada stasiun kerja secara berurutan dalam lini perakitan dengan menggunakan aturan largest candidate rules (LCR). Setelah itu, bila terdapat dua elemen pengerjaan cukup ditempatkan pada satu stasiun, maka dipilih elemen kerja dengan waktu yang lebih besar untuk ditempatkan pertama. Langkah terakhjr adalah membuat tabel dengan matriks $\mathrm{P}$ dan matriks $\mathrm{F}$, dimana matriks $\mathrm{P}$ menunjukkan pengerjaan pendahulu masing-masing elemen dan matriks $F$ menunjukkan pengerjaan pengikut untuk tiap elemen untuk tiap prosedur penugasan.

B. Fase dua, pada fase ini berusaha untuk membagi waktu mengganggur secara merata untuk seluruh stasiun kerja. Berikut merupakan langkah-langkah dalam fase dua ini adalah sebagai berikut :

a) Hitung waktu total operasi dari masingmasing stasiun kerja

b) Tentukan stasiun kerja yang memilik waktu operasi yang terbesar dan waktu operasi yang terkecil dari fase satu.

c) Setengah dari perbedaan kedua nilai tersebut dinamakan GOAL

d) Tetapkan seluruh elemen tunggal pada STmax yang kurang dari 2 kali nilai GOAL, dan tidak melanggar aturan precedence jika dipindahkan ke STmin.

e) Tetapkan seluruh kemungkinan pemindahan operasi dari STmax ke STmin, seperti halnya operasi maksimal 2 kali GOAL, dengan memperhatikan precedence.

f) Lakukan langkah diatas hingga tidak ada lagi yang bisa dipindahkan.

\section{Metode $J$-Wagon}

Metode ini mengutamakan jumlah elemen kerja yang terbanyak, dimana elemen kerja tersebut akan diprioritaskan terlebih dahulu untuk ditempatkan dalam stasiun kerja dan 
diikuti oleh elemen kerja yang memiliki jumlah elemen kerja yang lebih sedikit [5]. Berikut merupakan langkah-langkah dari metode $J$ Wagon adalah sebagai berikut:

a. Lakukan penjumlahan elemen kerja dari masing-masing operasi berdasarkan jumlah operasi kepada precedence yang ada.

b. Urutkan/ranking operasi-operasi berdasarkan jumlah operasi terbanyak.

c. Alokasikan operasi yang mempunyai ranking paling awal kepada stasiun yang lebih awal dengan memperhatikan precedence diagram.

d. Alokasikan seluruh operasi kepada seluruh seluruh stasiun yang ada.

e. Pengalokasian operasi kepada salah satu stasiun, total waktu prosesnya tidak boleh melebihi $\mathrm{C}_{\mathrm{T}}$ (Cycle Time) yang telah ditentukan.

\section{METODE PENELITIAN}

Metodologi penelitian dimulai dengan mengidentifikasi masalah yang ada di perusahaan tersebut. Setelah mendapatkan problematika yang ada dalam bidang pengecatan dan sering terjadinya ketidakseimbangan lini kemudian dilanjutkan dengan studi pustaka.

Data-data yang dikumpulkan adalah data permintaan dari perusahaan sehingga diperoleh target produksi per hari. Setelah itu dilanjutkan dengan pengukuran waktu pengerjaan dari setiap aktivitas yang ada dalam bagian pengecatan tersebut. Data-data lain yang diperoleh adalah waktu tata letak dan kapasitas produksi per elemen kerja.

Setelah semua pengumpulan data diperoleh maka dilakukan beberapa uji dari data waktu per aktivitas yang diperoleh. Uji yang pertama adalah uji kenormalan data, apakah data yang diperoleh normal dengan tingkat kepercayaan dan tingkat ketelitian tertentu yang diyakini. Uji yang kedua adalah uji keseragaman data, apakah data yang diperoleh sudah seragam atau masih belum seragam? Uji yang ke tiga dari data waktu yang diperoleh adalah uji kecukupan data. Jika semua uji belum sesuai maka masih ada kelanjutan dalam pengumpulan data lagi, tapi apabila data yang diperoleh sudah normal, seragam dan cukup maka data sudah bisa diolah untuk ke tahap selanjutnya.

Data yang sudah melalui beberapa tahap uji selanjutnya akan dioleh dengan 4 metode Heuristik dari keseimbangan lini yaitu: Metode Killbridge Wester (Region Approach), Metode Helgeson-Birnie, Metode Moodie Young dan Metode J Wagon. Dari ke empat metode ini akan dipilih metode keseimbangan lini yang terbaik dari beberapa kriteria yang dapat dipenuhi. Kriteria-kriteria tersebut adalah: efisiensi lini, balance delay, smoothness index, waktu siklus terpanjang, waktu mengganggur dan jumlah stasiun baru yang terbentuk.

Setelah membandingkan hasil perbandingan 4 metode dengan kriteria-kriteria yang bisa dipenuhi serta melihat tata letak yang ada, maka akan diperoleh hasil kesimpulan metode keseimbangan lini terbaik dari permasalah ketidakseimbangan lini di area produksi perusahaan ini.

\section{HASIL DAN PEMBAHASAN \\ Pengumpulan Data}

Aliran proses produksi plastic painting line J dapat dilihat pada Gambar 1.

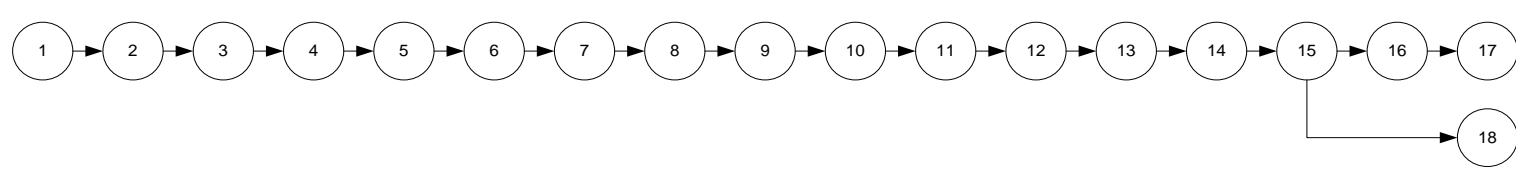

Gambar 1. Aliran Proses Produksi

Keterangan gambar:
1. Loading
2. Wiping $A$
3. Wiping $B$
4. Air blow
6. Under coat 2
7. Top under 1
8. Flash off
5. Under coat 1
9. Top under 2
10. Top coat 1
11. Top coat 2
12. Setting room
13. Oven
14. Unloading
15. Check

16. Buffing

17. Check

18. Sanding 


\section{Pengolahan Data}

Pengujian data salah satu proses dapat dilihat pada Tabel 1, Gambar 3, dan Tabel 2.

Tabel 1. Uji Kenormalan Data

\begin{tabular}{ccc}
\hline & & Loading \\
\cline { 3 - 3 } N & & Mean \\
Normal Parameters & a,b & Std. \\
& Deviation &, 36307 \\
& Absolute &, 185 \\
Most Extreme & Positive &, 185 \\
Differences & Negative &,- 142 \\
\hline Kolmogorov-Smirnov Z & 1,172 \\
Asymp. Sig. (2-tailed) &, 128 \\
\hline
\end{tabular}

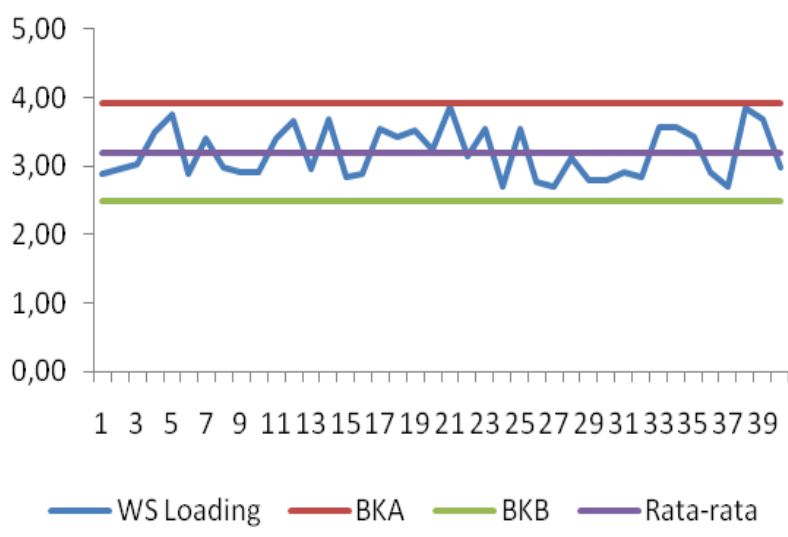

Gambar 2. Uji Keseragaman Data

Tabel 2. Uji Kecukupan Data

\begin{tabular}{cc}
\hline & Loading \\
\hline $\mathrm{N}^{\prime}$ & 19,27 \\
$\mathrm{~N}$ & 40 \\
\hline
\end{tabular}

Dari hasil perhitungan statistik untuk uji kenormalan data, keseragaman dan kecukupan data diperoleh bahwa hasil pengujian data menunjukkan bahwa data layak. Data waktu yang diperoleh normal dan seragam karena masuk dalam batas kontrol atas dan batas kontrol bawah, sedangkan data kecukupan data cukup hanya 20 data sedangkan data waktu yang dihitung adalah 40 data.

Hasil ini mungkin untuk aktivitas yang rutin dilakukan dan yang melakukan juga sudah biasa melakukan aktivitas tersebut sehingga tidak terlalu besar perbedaan data waktu dari yang pertama sampai ke data yang ke 40. Maka data waktu-waktu di atas sudah cukup untuk dapat digunakan untuk menghitung waktu baku tiap proses.
Adapun hasil waktu baku tiap proses terdapat pada Tabel 3.

Tabel 3. Waktu Baku Setiap Proses

\begin{tabular}{ccc}
\hline No & Aktivitas & Waktu Baku (detik) \\
\hline 1 & Loading & 4,25 \\
2 & Wiping A & 11,30 \\
3 & Wiping B & 7,95 \\
4 & Air blow & 9,05 \\
5 & Under coat 1 & 20,66 \\
6 & Under coat 2 & 20,11 \\
7 & Top under 1 & 25,02 \\
8 & Flash off & 21,89 \\
9 & Top under 2 & 28,28 \\
10 & Top coat 1 & 27,88 \\
11 & Top coat 2 & 4,28 \\
12 & Setting room & 12,36 \\
13 & Oven & 23,02 \\
14 & Unloading & 13,91 \\
15 & Check & 24,52 \\
16 & Buffing & 4,25 \\
17 & Check & 11,30 \\
18 & Sanding & 7,95 \\
\hline & Total & 347,48 \\
\hline
\end{tabular}

\section{Analisis Data}

Output dari proses produksi pada plastic painting line J perhari yaitu sebesar 1500 unit. Waktu yang tersedia untuk memproduksi output pada shift pertama yaitu 440 menit dan pada shift kedua yaitu 380 menit.

Waktu produksi perhari $=(440 \times 60)+(380 \times 60)$

$$
=49.200 \text { detik }
$$

Waktu siklus $=\frac{\text { waktu produksi perhari }}{\text { permintaan perhari }}=\frac{49200}{1500}$

$$
=32,80 \text { detik }
$$

Jumlah stasiun kerja $(\mathrm{N})=\frac{\text { total waktu proses }}{\text { waktu siklus }}=$

$$
\begin{aligned}
\frac{347,48}{32,80}=10,59 \approx 11 \text { stasiun } & \\
& =\frac{347,48}{32,80}=10,59 \\
& \approx 11 \text { stasiun }
\end{aligned}
$$

Pembentukan stasiun kerja baru berdasarkan metode keseimbangan lini dapat dilihat pada Tabel 4, Tabel 5, Tabel 6, dan Tabel 7.

Dengan metode Kilbridge-Wester, efisiensi lini yang didapatkan yaitu sebesar 76,24\% dengan 14 stasiun kerja serta balance delay sebesar $23,76 \%$ dan smoothness index yaitu sebesar 35,65. 
Tabel 4. Stasiun Kerja Baru dengan Metode Kilbridge-Wester

\begin{tabular}{cccc}
\hline $\begin{array}{c}\text { Stasiun } \\
\text { Kerja }\end{array}$ & $\begin{array}{c}\text { Elemen } \\
\text { Kerja }\end{array}$ & $\begin{array}{c}\text { Waktu Baku } \\
\text { (detik) }\end{array}$ & $\begin{array}{c}\text { Total Waktu } \\
\text { Baku (detik) }\end{array}$ \\
\hline & 1 & 4,25 & \\
1 & 2 & 11,30 & 32,55 \\
& 3 & 7,95 & \\
& 4 & 9,05 & 20,66 \\
2 & 5 & 20,66 & 20,11 \\
3 & 6 & 20,11 & 25,02 \\
4 & 7 & 25,02 & 31,00 \\
5 & 8 & 31,00 & 21,89 \\
6 & 9 & 21,89 & 28,28 \\
7 & 10 & 4,25 & 27,88 \\
8 & 11 & 11,30 & 31,00 \\
9 & 12 & 7,95 & 31,00 \\
10 & 13 & 31,00 & 16,63 \\
11 & 14 & 4,28 & 23,02 \\
12 & 15 & 12,36 & 13,91 \\
13 & 16 & 23,02 & 24,52 \\
14 & 17 & 13,91 &
\end{tabular}

Tabel 5. Stasiun Kerja Baru dengan Metode

\begin{tabular}{cccc}
\multicolumn{4}{c}{ Helgeson-Birnie } \\
\hline $\begin{array}{c}\text { Stasiun } \\
\text { Kerja }\end{array}$ & $\begin{array}{c}\text { Elemen } \\
\text { Kerja }\end{array}$ & $\begin{array}{c}\text { Waktu Baku } \\
\text { (detik) }\end{array}$ & $\begin{array}{c}\text { Total Waktu } \\
\text { Baku (detik) }\end{array}$ \\
\hline & 1 & 4,25 & \\
1 & 2 & 11,30 & 32,55 \\
& 3 & 7,95 & \\
& 4 & 9,05 & 20,66 \\
2 & 5 & 20,66 & 20,11 \\
3 & 6 & 20,11 & 25,02 \\
4 & 7 & 25,02 & 31,00 \\
5 & 8 & 31,00 & 21,89 \\
6 & 9 & 21,89 & 28,28 \\
7 & 10 & 28,28 & 27,88 \\
8 & 11 & 27,88 & 31,00 \\
9 & 12 & 31,00 & 31,00 \\
10 & 13 & 31,00 & 16,63 \\
11 & 14 & 4,28 & 23,02 \\
12 & 15 & 12,36 & 24,52 \\
13 & 16 & 23,02 & 13,91 \\
14 & 18 & 24,52 &
\end{tabular}

Efisiensi lini yang didapatkan dengan metode Helgeson-Birnie yaitu sebesar 76,24\% dengan 14 stasiun kerja serta balance delay sebesar 23,76\% dan smoothness index yaitu sebesar 35,65.

Dengan menggunakan metode Moodie Young, efisiensi lini yang didapatkan yaitu sebesar 80,06\% dengan 14 stasiun kerja serta balance delay sebesar 19,94\% dan smoothness index yaitu sebesar 29,08.
Tabel 6. Stasiun Kerja Baru dengan Metode Moodie Young

\begin{tabular}{cccc}
\hline $\begin{array}{c}\text { Stasiun } \\
\text { Kerja }\end{array}$ & $\begin{array}{c}\text { Elemen } \\
\text { Kerja }\end{array}$ & $\begin{array}{c}\text { Waktu Baku } \\
\text { (detik) }\end{array}$ & $\begin{array}{c}\text { Total Waktu } \\
\text { Baku (detik) }\end{array}$ \\
\hline & 2 & 11,30 & \\
1 & 3 & 7,95 & 28,30 \\
& 4 & 9,05 & \\
2 & 5 & 20,66 & 20,66 \\
3 & 6 & 20,11 & 20,11 \\
4 & 7 & 25,02 & 25,02 \\
5 & 8 & 31,00 & 31,00 \\
6 & 9 & 21,89 & 21,89 \\
7 & 10 & 28,28 & 28,28 \\
8 & 11 & 27,88 & 27,88 \\
9 & 12 & 31,00 & 31,00 \\
10 & 13 & 31,00 & 31,00 \\
11 & 14 & 4,28 & 16,63 \\
12 & 15 & 12,36 & 23,02 \\
13 & 16 & 23,02 & 18,16 \\
14 & 1 & 13,91 & 24,52 \\
\hline
\end{tabular}

Tabel 7. Stasiun Kerja Baru dengan Metode

\begin{tabular}{cccc}
\multicolumn{4}{c}{ J-Wagon } \\
$\begin{array}{c}\text { Stasiun } \\
\text { Kerja }\end{array}$ & $\begin{array}{c}\text { Elemen } \\
\text { Kerja }\end{array}$ & $\begin{array}{c}\text { Waktu Baku } \\
\text { (detik) }\end{array}$ & $\begin{array}{c}\text { Total Waktu } \\
\text { Baku (detik) }\end{array}$ \\
\hline & 1 & 4,25 & \\
1 & 2 & 11,30 & 32,55 \\
& 3 & 7,95 & \\
& 4 & 9,05 & \\
2 & 5 & 20,66 & 20,66 \\
3 & 6 & 20,11 & 20,11 \\
4 & 7 & 25,02 & 25,02 \\
5 & 8 & 31,00 & 31,00 \\
6 & 9 & 21,89 & 21,89 \\
7 & 10 & 28,28 & 28,28 \\
8 & 11 & 27,88 & 27,88 \\
9 & 12 & 31,00 & 31,00 \\
10 & 13 & 31,00 & 31,00 \\
11 & 14 & 4,28 & 16,63 \\
12 & 15 & 12,36 & \\
13 & 16 & 23,02 & 23,02 \\
14 & 17 & 24,52 & 24,52 \\
& 18 & 13,91 & 13,91 \\
\hline
\end{tabular}

Efisiensi lini yang didapatkan dengan metode $J$-Wagon yaitu sebesar 76,24\% dengan 14 stasiun kerja serta balance delay sebesar $23,76 \%$ dan smoothness index yaitu sebesar 35,65 .

Hasil perbandingan efisiensi lini, balance delay, smoothness index, waktu menganggur, dan jumlah stasiun dapat dilihat pada Tabel 8 . 
Tabel 8. Perbandingan efisiensi, balance delay, dan smoothness index

\begin{tabular}{lccccc}
\hline & Lini Awal & Kilbridge-Wester & Helgeson-Birnie & Moodie Young & J-Wagon \\
\hline Efisiensi lini & $61,78 \%$ & $76,58 \%$ & $76,58 \%$ & $\mathbf{7 9 , 4 4 \%}$ & $76,58 \%$ \\
Balance delay & $38,22 \%$ & $23,42 \%$ & $23,42 \%$ & $\mathbf{2 0 , 5 6 \%}$ & $23,42 \%$ \\
Smoothness index & 63,34 & 35,21 & 35,21 & $\mathbf{2 9 , 9 1}$ & 35,21 \\
Waktu siklus terpanjang & 31 detik & 32,16 detik & 32,16 detik & $\mathbf{3 1 ~ d e t i k}$ & 32,16 detik \\
Waktu menganggur & 213,24 detik & 105,45 detik & 105,45 detik & $\mathbf{8 9 , 2 4 ~ d e t i k}$ & 105,45 detik \\
Jumlah stasiun & 18 & 14 & 14 & $\mathbf{1 4}$ & 14 \\
\hline
\end{tabular}

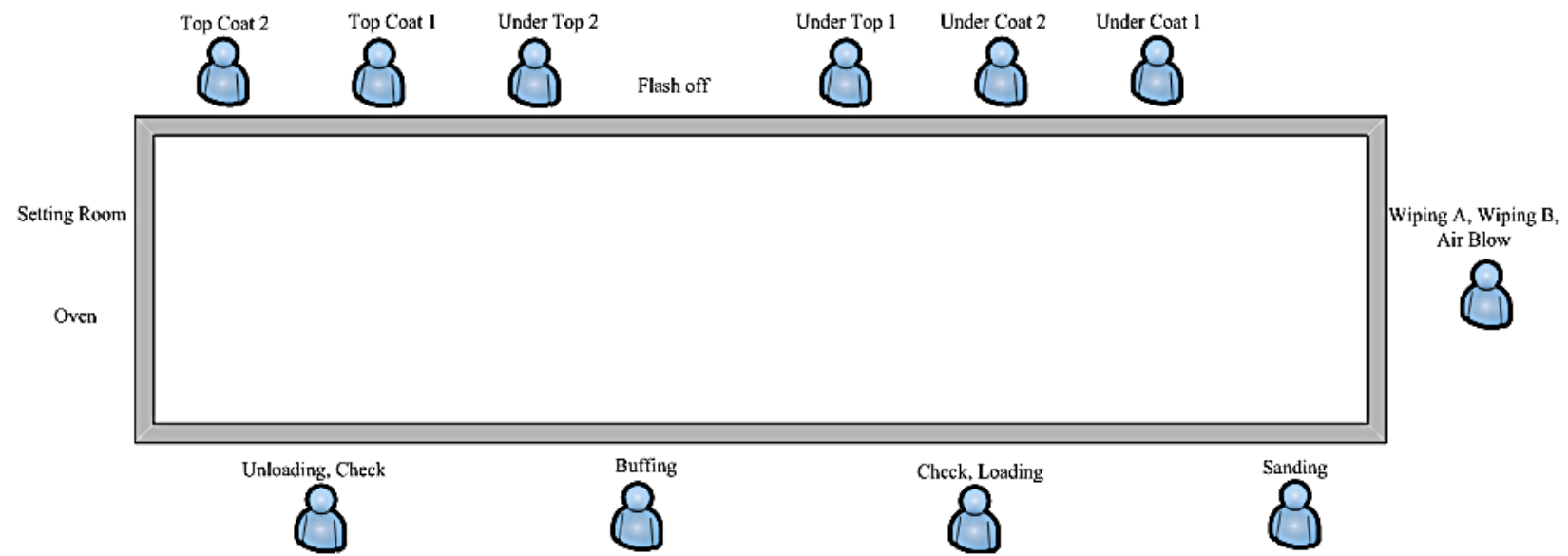

Gambar 4. Layout Lantai Produksi Berdasarkan Metode Moodie Young

Layout lantai produksi dengan menggunakan metode Moodie Young dapat dilihat pada Gambar 4.

\section{KESIMPULAN}

Kesimpulan yang didapat dari hasil penelitian yaitu sebagai berikut: jumlah pekerja dalam keadaan lini awal yaitu sebanyak 15 orang pekerja dengan jumlah stasiun kerja yaitu 18 stasiun, dimana elemen kerja 8, 12, dan 13 tidak memerlukan pekerja. Dengan metode keseimbangan lini yang digunakan, maka didapatkan jumlah tenaga kerja sebanyak 11 orang pekerja dengan 14 stasiun kerja. Hal ini berarti secara keseluruhan, divisi plastic painting line $\mathrm{J}$ mengurangi 4 orang pekerja. Efisiensi optimum didapatkan dengan menggunakan metode Moodie Young yaitu sebesar 80,06\%, dimana efisiensi awal yaitu $62,27 \%$. Balance delay dalam keadaan lini awal yaitu sebesar 37,73 . Sedangkan balance delay minimum yang diperoleh menggunakan metode Moodie Young yaitu sebesar 19,04\%. Smoothness index dalam keadaan lini awal yaitu sebesar 62,75. Dengan metode Moodie Young, maka smoothness index minimum yang dicapai yaitu 29,08. Waktu menganggur minimum dalam keadaan lini awal yaitu 210,52 detik. Dengan menggunakan metode Moodie Young, waktu menganggur minimum yang didapatkan yaitu sebesar 86,52 detik. Hal ini menunjukkan pengurangan waktu menganggur sebesar 124 detik.

\section{DAFTAR PUSTAKA}

[1]. Sutalaksana, Iftikar Z. Ruhana Anggawisastra \& Jann H, Tjakraatmadja. 2006. Teknik Perancangan Sistem Kerja. Bandung: Institut Teknik Bandung.

[2]. Gaspersz, Vincent. 2000. Manajemen Produktivitas Total. Jakarta: Gramedia.

[3]. Saptanti, Dyah. 2008. Perbandingan Metode Ranked Positional Weight dan Kilbridge Wester Pada Permasalahan Keseimbangan Lini Lintasan Produksi Berbasis Single Mode., Bandung : Institut Teknologi Bandung

[4]. Yudistira, Satria. (2008). Analisis Keseimbangan Lini Perakitan Model CJM 1.5 Dengan Metode Rank Positional Weight Di PT. KRM, Jakarta: Universitas Bina Nusantara

[5]. Chase, R B., F.R Jacobs and N.J. Aquilano, 2009 Operation Supply Management $12^{\text {th }}$ ed, Mc Graw Hill. NY 